\title{
IMPLEMENTASI FINITE STATE AUTOMATA (FSA) DENGAN SIMULASI VENDING MACHINE PADA APLIKASI ANDROID
}

\author{
Ahmad Saufi Maulana ${ }^{1}$, Hanifah Nur Azizah ${ }^{2}$, Kartika Candra Kirana ${ }^{3}$ \\ 1,2,3 Jurusan Teknik Elektro Universitas Negeri Malang \\ email : ahmadsaufimaulana@gmail.com
}

\begin{abstract}
Theory of Language and Automata is part of computer science, which is useful as a means of human and machine communication. Otomata theory is a theory of abstract machines, and is closely related to formal language theory. Automata can be applied in vending machines. A vending machine is a vending machine that sells goods. A vending machine is a beverage vending machine that can be done independently to serve beverage or snack purchase transactions. The implementation of Finite State Automata with the simulation of a Vending Machine on an Android application is expected to provide convenience for users in understanding the concepts and ways of working of a Vending Machine and to be implemented as needed.
\end{abstract}

Keywords: Android, Vending Machine, Vending Machine Simulation, and Finite State Automata.

\begin{abstract}
ABSTRAK
Teori Bahasa dan Automata merupakan bagian dari ilmu komputer, yang berguna sebagai perantara komunikasi manusia dan mesin. Teori Otomata adalah teori mengenai mesin-mesin abstrak, dan berkaitan erat dengan teori bahasa formal. Automata dapat diterapkan dalam mesin vending machine. Vending machine merupakan suatu alat atau mesin yang menjual barang secara otomatis. Vending machine adalah sebuah mesin penjual minuman yang dapat beroperasi secara standalone untuk melayani transaksi pembelian minuman atau makanan kecil. Implementasi Finite State Automata dengan simulasi Vending Machine pada aplikasi Android diharapkan dapat memberikan kemudahan bagi pengguna dalam memahami konsep dan cara kerja dari sebuah Vending Machine dan agar dapat diterapkan sesuai dengan kebutuhan.
\end{abstract}

Kata kunci: Android, Vending Machine, Vending Machine Simulation, and Finite State Automata.

\section{PENDAHULUAN}

Pada dasarnya, kemajuan ilmu pengetahuan membawa perubahan besar dalam kehidupan manusia, baik yang berdampak positif maupun negatif. Manusia banyak menemukan penemuan baru yang dibutuhkan untuk kelangsungan hidup. Salah satunya adalah mesin penjual otomatis yang merupakan karya Heron yang berasal dari Alexandria. Mesin penjual otomatis moden pertama diperkenalkan di London, Inggris pada awal tahun 1880 an yaitu mesin penjual kartu pos otomatis. Mesin penjual otomatis (Inggris: Vending Machine) adalah mesin yang dapat mengeluarkan barang-barang seperti makanan ringan, minuman kaleng, dan produk konsumen lainnya untuk pelanggan secara otomatis. Seperti penjual asli, mesin ini akan mengeluarkan barang yang kita inginkan setelah kita memasukkan sejumlah koin/ uang kertas (Wamiliana dan Rahmadhani, 2013).

Vending Machine membutuhkan uang untuk proses kerjanya. Terdapat lubang sebagai 
tempat untuk memasukkan uang pada mesin sejumlah yang ditentukan. Setelah dimasukkan uang, user dapat memilih minuman yang akan dibelinya. Setelah minuman terpilih, otomatis mesin akan menjatuhkan minuman yang sesuai, dan yang terakhir user dapat mengambil minuman dari balik pintu kecil yang telah disediakan. Untuk mengatasi permasalahan dalam proses pembelian minuman secara otomatis ini, membutuhkan penerapan konsep Finite State Automata (FSA).

Finite State Automata (FSA) adalah model matematika yang dapat menerima input dan mengeluarkan output yang memiliki state yang berhingga banyaknya dan dapat berpindah dari satu state ke state lainnya berdasarkan input dan fungsi transisi. Dari jenisnya yaitu Finite State Automata (FSA) terdapat mesin bahasa yang berarti dia dapat mengenali, menerima dan menolak yang terdapat pada mesin FSA jenis DFA (Deterministic Finite Automata) dan NFA (Non-deterministic Finite Automata) (K. Kim, dkk., 2014). FSA output berbeda dengan jenis FSA sebelumnya (DFA \& NFA), pada jenis ini tidak terdapat state menerima dan menolak, memiliki fungsi \& himpunan output (M. Syai, dkk., 2017).

Di Indonesia, keberadaan vending machine masih dapat dikatakan langka. Oleh karena itu, munculah keinginan untuk mencoba mempelajari cara kerja vending machine sekaligus menerapkan bagian dari Teori Bahasa dan Automata untuk merancang dan membuat simulasinya.

Automata merupakan suatu sistem yang terdiri atas sejumlah berhingga state, di mana state menyatakan informasi mengenai input. Automata juga dianggap sebagai mesin otomatis (bukan mesin fisik) yang merupakan suatu model matematika dari suatu sistem yang menerima input dan menghasilkan output, serta terdiri dari sejumlah berhingga state (F. Utdirartatmo, 2019).
Sudiadi dan Rizadi (2017) berpendapat bahwa hubungan di antara bahasa dan automata adalah bahasa dijadikan sebagai input oleh suatu mesin automata, selanjutnya mesin automata akan membuat keputusan yang mengindikasikan apakah input itu diterima atau tidak.

Finite State Automata (FSA) merupakan mesin automata dari bahasa regular. Suatu Finite State Automata memiliki state yang banyaknya berhingga, dan dapat berpindahpindah dari suatu state ke state lain. Secara formal finite state automata dinyatakan oleh 5 tupel atau $\mathrm{M}=(\mathrm{Q}, \Sigma, \delta, \mathrm{S}, \mathrm{F})$, di mana :

$\mathrm{Q}=$ himpunan state / kedudukan

$\Sigma=$ himpunan simbol input / masukan / abjad

$\delta=$ fungsi transisi

$\mathrm{S}=$ state awal / kedudukan awal (initial state)

$\mathrm{F}=$ himpunan state akhir (Widyasari, 2011).

Vending machine merupakan suatu alat atau mesin yang menjual barang secara otomatis untuk memudahkan konsumen membeli minuman atau makanan ringan, sehingga proses jual-beli dapat lebih mudah, efisiensi, praktis dan tidak menghabiskan waktu yang banyak (Rudi, 2014).

Android adalah sistem operasi bersifat open source berbasis Linux dirancang untuk perangkat seluler layar sentuh seperti telepon pintar dan komputer tablet. Android awalnya dikembangkan oleh Android, Inc., dengan dukungan finansial dari Google, yang kemudian membelinya pada tahun 2005. Sistem operasi ini dirilis secara resmi pada tahun 2007, bersamaan dengan didirikannya Open Ponsel Android pertama mulai dijual pada bulan Oktober 2008 (N. Safat, 2012). Kemudian untuk mengembangkan Android, dibentuklah Open Handset Alliance yang merupakan konsorsium dari 34 perusahaan perangkat keras, perangkat lunak dan telekomunikasi (L. Glenn, 2013). 


\section{METODE}

Sistem implementasi FSA dengan simulasi vending machine pada aplikasi android dirancang dengan menggunakan UML (Unified Modelling Language) yang terdiri dari use case diagram dan activity diagram. Usecase diagram mendeskripsikan sistem dari sudut pandang user dan admin.

Usecase diagram digunakan untuk melihat secara visual bagaimana implementasi perwujudan atau interaksi kejadian yang terjadi antara pengguna dengan vending machine. Sistem dirancang menjadi dua, yaitu user itu sendiri dan admin.

Diagram FSA dibuat untuk melihat model matematika dari sistem simulasi vending machine pada aplikasi android yang menerima input dan output diskrit yang terdiri dari user dan admin .

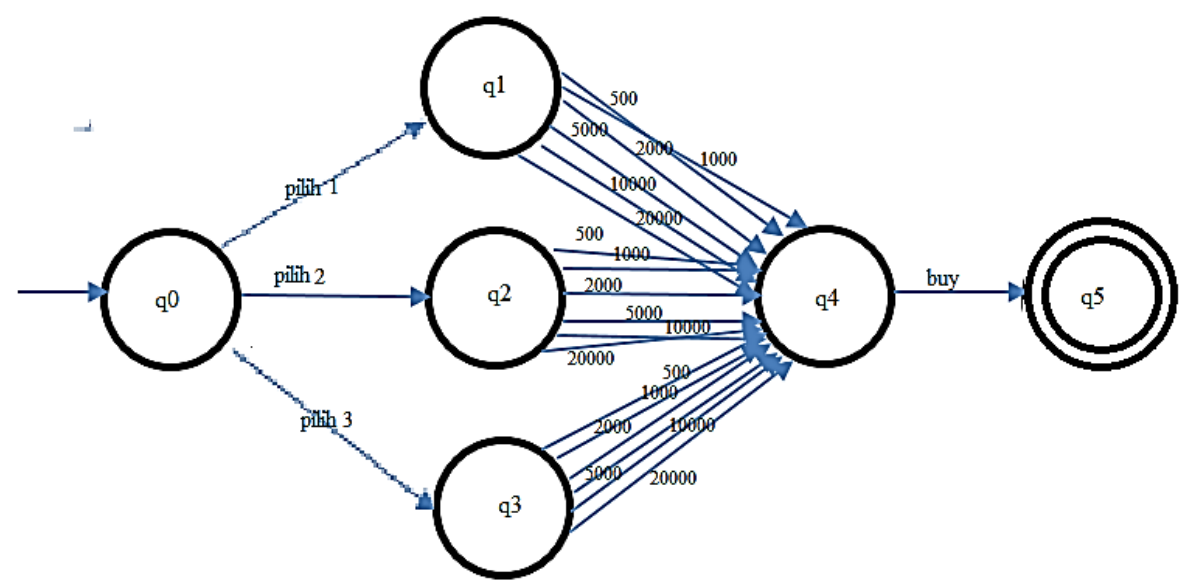

Gambar 1. Diagram FSA Pembeli

Keterangan :

$\mathrm{Q}=\{\mathrm{q} 0, \mathrm{q} 1, \mathrm{q} 2, \mathrm{q} 3, \mathrm{q} 4, \mathrm{q} 5\}$

$\mathrm{E}=\{$ pilih, 500, 1000, 2000, 5000, 10000, 20000 , buy

$\mathrm{S}=\{\mathrm{q} 0\}$

$F=\{q 5\}$

Tabel 1. Transisi Pembeli

\begin{tabular}{|c|c|c|c|c|c|c|c|c|c|c|}
\hline q & Pilih1 & Pilih2 & Pilih3 & 500 & 1000 & 2000 & 5000 & 10000 & 20000 & buy \\
\hline q0 & $\mathrm{q} 1$ & $\mathrm{q} 2$ & $\mathrm{q} 3$ & - & - & - & - & - & - & - \\
\hline $\mathrm{q} 1$ & - & - & - & $\mathrm{q} 4$ & $\mathrm{q} 4$ & $\mathrm{q} 4$ & $\mathrm{q} 4$ & $\mathrm{q} 4$ & $\mathrm{q} 4$ & - \\
\hline $\mathrm{q} 2$ & - & - & - & $\mathrm{q} 4$ & $\mathrm{q} 4$ & $\mathrm{q} 4$ & $\mathrm{q} 4$ & $\mathrm{q} 4$ & $\mathrm{q} 4$ & - \\
\hline $\mathrm{q} 3$ & - & - & - & $\mathrm{q} 4$ & $\mathrm{q} 4$ & $\mathrm{q} 4$ & $\mathrm{q} 4$ & $\mathrm{q} 4$ & $\mathrm{q} 4$ & - \\
\hline $\mathrm{q} 4$ & - & - & - & - & - & - & - & - & - & $\mathrm{q} 5$ \\
\hline $\mathrm{q} 5$ & - & - & - & - & - & - & - & - & - & - \\
\hline
\end{tabular}

Keterangan :

1. Proses $\mathrm{q} 0$ ke $\mathrm{q} 1 / \mathrm{q} 2 / \mathrm{q} 3=$ memilih minuman

2. Proses $\mathrm{q} 1 / \mathrm{q} 2 / \mathrm{q} 3 \mathrm{ke} \mathrm{q} 4=$ memasukkan uang

3. Proses $\mathrm{q} 4$ ke $\mathrm{q} 5=$ beli, transaksi berhasil 


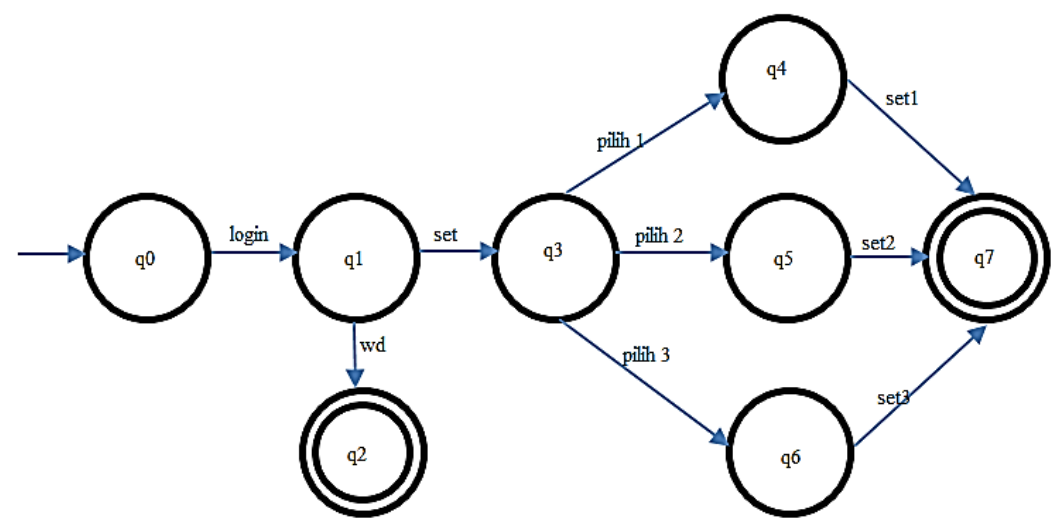

Gambar 2. Diagram FSA Admin

Keterangan :

$\mathrm{Q}=\{\mathrm{q} 0, \mathrm{q} 1, \mathrm{q} 2, \mathrm{q} 3, \mathrm{q} 4, \mathrm{q} 5, \mathrm{q} 6, \mathrm{q} 7\}$

$\mathrm{E}=\{$ login, set, wd, pilih1, pilih2, pilih3, set1, set2, set3 $\}$

$\mathrm{S}=\{\mathrm{q} 0\}$

$\mathrm{F}=\{\mathrm{q} 2, \mathrm{q} 7\}$

Tabel 2. Transisi Admin

\begin{tabular}{|c|c|c|c|c|c|c|c|c|c|}
\hline Q & login & set & Pilihl & Pilih2 & Pilih3 & Set1 & Set2 & Set3 & Wd \\
\hline q0 & q1 & - & - & - & - & - & - & - & - \\
\hline q1 & - & $\mathrm{q} 3$ & - & - & - & - & - & - & q2 \\
\hline q2 & - & - & - & - & - & - & - & - & - \\
\hline q3 & - & - & q4 & q5 & q6 & - & - & - & - \\
\hline q4 & - & - & - & - & - & q7 & - & - & - \\
\hline q5 & - & - & - & - & - & - & q7 & - & - \\
\hline q6 & - & - & - & - & - & - & - & q7 & - \\
\hline q7 & - & - & - & - & - & - & - & - & - \\
\hline
\end{tabular}

Keterangan :

1. Proses $\mathrm{q} 0 \mathrm{ke} \mathrm{q} 1=\operatorname{login}$

2. Proses $\mathrm{q} 1 \mathrm{ke} \mathrm{q} 2=$ mengambil uang

3. Proses $\mathrm{q} 1 \mathrm{ke} \mathrm{q} 3=$ pilih menu set item stock

4. Proses q3 ke q4/q5/q6 = memilih minumanProses q4/q5/q6 ke q7 = masukkan jumlah minuman yang akan ditambahkan

Prosedur simulasi penggunaan vending machine ini mengacu pada desain Finite State Automata yang telah dibuat. Adapun prosedur penggunaan simulasi vending machine adalah sebagai berikut:

Prosedur sebagai User

1. Memilih jenis minuman

2. Memasukkan uang kedalam vending machine

3. Mengambil minuman yang telah dipilih dan mengambil uang kembalian (jika ada)

Prosedur sebagai Admin
1. Login
2. Set stock product
3. Mengambil uang

Untuk merancang sebuah implementasi finite state automata (FSA) dengan simulasi vending machine pada aplikasi android, maka 
diperlukan konsep sederhana untuk menjalankan implementasi vending machine tersebut, adapun berikut adalah aturan yang berlaku pada vending machine:

1. Pada simulasi vending machine ini, dimasukkan 3 jenis produk minuman yaitu "mizone" dengan harga Rp5.500, "hydro coco" dengan harga Rp5.000, dan "pocari sweat" dengan harga Rp8.000.

2. Menetapkan aturan uang minimal yaitu Rp500, dan uang maksimal yaitu Rp20.000 yang bisa dimasukkan oleh pengguna, dengan spesifikasi uang koin yaitu Rp500 dan Rp1.000; dan uang kertas yaitu Rp2.000, Rp5.000, Rp10.000, dan Rp20.000.

Adapun penambahan indikator pemesanan dan sistem kembalian dalam simulasi vending machine dengan aturan seperti pada tabel 3 .

Tabel 3. Indikator Pemesanan Dan Sistem Kembalian Minuman Mizone

\begin{tabular}{|c|c|c|c|c|}
\hline Jenis & \multicolumn{4}{|c|}{ Mizone } \\
\hline Harga & No. & Rp5.500 & Jumlah & Kembalian \\
\hline \multirow{2}{*}{$\begin{array}{c}\text { Kemungki } \\
\text { nan Uang } \\
\text { Koin yang } \\
\text { dimasukka } \\
n\end{array}$} & 1. & $500 \times 11$ & 5.500 & - \\
\hline & 2. & $\begin{array}{c}1000 \times 5+ \\
500\end{array}$ & 5.500 & - \\
\hline \multirow{3}{*}{$\begin{array}{c}\text { Kemungki } \\
\text { nan Uang } \\
\text { Kertas } \\
\text { yang } \\
\text { dimasukka } \\
\text { n } \\
\end{array}$} & 3. & $\begin{array}{c}5.000+ \\
2000\end{array}$ & 7.000 & 1.500 \\
\hline & 4. & 10.000 & 10.000 & 3.500 \\
\hline & 5. & 20.000 & 20.000 & 14.500 \\
\hline \multirow{3}{*}{$\begin{array}{c}\text { Kemungki } \\
\text { nan Uang } \\
\text { Koin dan } \\
\text { Kertas } \\
\text { yang } \\
\text { dimasukka } \\
n\end{array}$} & 6. & $\begin{array}{c}5.000+ \\
500\end{array}$ & 5.500 & - \\
\hline & 7. & $\begin{array}{c}10.000+ \\
500\end{array}$ & 10.500 & 5.000 \\
\hline & $\begin{array}{c}\text { Dst } \\
\text {. }\end{array}$ & Dst. & Dst. & Dst. \\
\hline
\end{tabular}

Dari tabel indikator pemesanan dan sistem kembalian minuman mizone diatas, kita dapat mengetahui bahwa minuman mizone dengan harga Rp5.500 dapat kita beli dengan memasukkan sejumlah uang seperti dalam tabel dengan memerhatikan kolom kemungkinan uang yang dimasukkan. Sebagai contoh, jika kita memasukkan uang seperti pada nomor 3 dalam tabel diatas yaitu dengan memasukkan uang kertas Rp5.000 + Rp2.000 kita akan mendapat kembalian Rp1.500.

Kesimpulan yang dapat ditarik dari tabel indikator pemesanan dan sistem kembalian minuman mizone di atas yaitu peluang kemungkinan orang memasukkan uang koin Rp500 sebanyak 14 kali dan selanjutnya dibagi dengan jumlah kemungkinan memasukkan sejumlah uang yaitu ada 7, jadi 14/2=2; kemungkinan dimasukkan uang koin Rp1.000 sebanyak 5 kali dibagi $7=5 / 7$; kemungkinan dimasukkan uang kertas Rp2.000 sebanyak 1 kali dibagi $7=1 / 7$; kemungkinan dimasukkan uang kertas Rp5.000 sebanyak 2 kali dibagi $7=$ 2/7; kemungkinan dimasukkan uang kertas Rp10.000 sebanyak 2 kali dibagi $7=2 / 7$; dan kemungkinan dimasukkan uang kertas Rp20.000 sebanyak 1 kali dibagi $7=1 / 7$.

Tabel 4. Indikator Pemesanan dan Sistem Kembalian Minuman Hydro Coco

\begin{tabular}{|c|c|c|c|c|}
\hline Jenis & \multicolumn{4}{|c|}{ Hydro Coco } \\
\hline Harga & No. & Rp5.000 & Jumlah & Kembalian \\
\hline $\begin{array}{c}\text { Kemungkinan } \\
\text { Uang Koin }\end{array}$ & 1. & $500 \times 10$ & 5.000 & - \\
\cline { 2 - 5 } & 2. & $1000 \times 5$ & 5.000 & - \\
\hline $\begin{array}{c}\text { Kemungkinan } \\
\text { Uang Kertas }\end{array}$ & 3. & 5.000 & 5.000 & - \\
\cline { 2 - 5 } & 4. & 10.000 & 10.000 & 5.000 \\
\cline { 2 - 5 } & 5. & 20.000 & 20.000 & 15.000 \\
\hline $\begin{array}{c}\text { Kemungkinan } \\
\text { Uang Koin } \\
\text { dan Kertas }\end{array}$ & 6. & $\begin{array}{c}2.000+ \\
1000 x 3\end{array}$ & 5.000 & - \\
\cline { 2 - 5 } & Dst. & Dst. & Dst. & Dst. \\
\hline \multicolumn{4}{|c|}{ Dari tabel indikator } & pemesanan dan \\
\hline
\end{tabular}

sistem kembalian minuman hydro coco, dapat diketahui bahwa minuman hydro coco dengan harga Rp5.000 dapat dibeli dengan memasukkan sejumlah uang seperti dalam tabel dengan memperhatikan kolom kemungkinan uang yang dimasukkan. Sebagai contoh, jika kita memasukkan uang seperti pada nomor 4 dalam tabel 4 yaitu dengan 
memasukkan uang kertas Rp10.000, kita akan mendapat kembalian Rp5.000.

Kesimpulan yang dapat ditarik dari tabel indikator pemesanan dan sistem kembalian minuman hydro coco yaitu peluang kemungkinan orang memasukkan uang koin Rp500 sebanyak 10 kali dan selanjutnya dibagi dengan jumlah kemungkinan memasukkan sejumlah uang yaitu ada 6 , jadi 10/6; kemungkinan dimasukkan uang koin Rp1.000 sebanyak 8 kali dibagi $6=8 / 6$; kemungkinan dimasukkan uang kertas Rp2.000 sebanyak 1 kali dibagi $6=1 / 6$; kemungkinan dimasukkan uang kertas Rp5.000 sebanyak 1 kali dibagi $6=$ 1/6; kemungkinan dimasukkan uang kertas Rp10.000 sebanyak 1 kali dibagi $1=1 / 7$; dan kemungkinan dimasukkan uang kertas Rp20.000 sebanyak 1 kali dibagi $6=1 / 6$.

Tabel 5. Indikator Pemesanan dan Sistem Kembalian Minuman Pocari Sweat

\begin{tabular}{|c|c|c|c|c|}
\hline Jenis & \multicolumn{4}{|c|}{ Pocari Sweat } \\
\hline Harga & No. & Rp8.000 & Jumlah & Kembalian \\
\hline \multirow[t]{2}{*}{$\begin{array}{c}\text { Kemungkinan } \\
\text { Uang Koin }\end{array}$} & 1. & $\begin{array}{c}500 x \\
16\end{array}$ & 8.000 & - \\
\hline & 2. & $\begin{array}{c}1000 x \\
8\end{array}$ & 8.000 & - \\
\hline \multirow[t]{3}{*}{$\begin{array}{l}\text { Kemungkinan } \\
\text { Uang Kertas }\end{array}$} & 3. & $\begin{array}{c}5.000+ \\
2000+ \\
1.000\end{array}$ & 8.000 & - \\
\hline & 4. & 10.000 & 10.000 & 2.000 \\
\hline & 5. & 20.000 & 20.000 & 12.000 \\
\hline \multirow{3}{*}{$\begin{array}{c}\text { Kemungkinan } \\
\text { Uang Koin } \\
\text { dan Kertas }\end{array}$} & 6. & $\begin{array}{c}5.000+ \\
1.000 \times 3\end{array}$ & 8.000 & - \\
\hline & 7. & $\begin{array}{c}5.000+ \\
2.000+ \\
1.000\end{array}$ & 8.000 & - \\
\hline & Dst. & Dst. & Dst. & Dst. \\
\hline
\end{tabular}

Dari tabel indikator pemesanan dan sistem kembalian minuman pocari sweat, dapat diketahui bahwa minuman pocari sweat dengan harga Rp8.000 dapat dibeli dengan memasukkan sejumlah uang seperti tabel 5 dengan memerhatikan kolom kemungkinan uang yang dimasukkan. Sebagai contoh, jika dimasukkan uang seperti pada nomor 4 dalam tabel 5 yaitu dengan memasukkan uang kertas Rp10.000 akan mendapat kembalian Rp2.000.

Kesimpulan yang dapat ditarik dari tabel indikator pemesanan dan sistem kembalian minuman pocari sweat yaitu peluang kemungkinan orang memasukkan uang koin Rp500 sebanyak 16 kali dan selanjutnya dibagi dengan jumlah kemungkinan memasukkan sejumlah uang yaitu ada 7 , jadi 16/7; kemungkinan dimasukkan uang koin Rp1.000 sebanyak 13 kali dibagi $7=13 / 7$; kemungkinan dimasukkan uang kertas Rp2.000 sebanyak 2 kali dibagi $7=2 / 7$; kemungkinan dimasukkan uang kertas Rp5.000 sebanyak 3 kali dibagi 7 = 3/7; kemungkinan dimasukkan uang kertas Rp10.000 sebanyak 1 kali dibagi $7=1 / 7$; dan kemungkinan dimasukkan uang kertas Rp20.000 sebanyak 1 kali dibagi $7=1 / 7$.

Sistem Kembalian Menggunakan Algoritma Optimasi. Algoritma optimasi merupakan suatu algoritma yang berfungsi untuk memecahkan persoalan dengan mencari solusi optimum. Dalam penelitian ini, algoritma optimasi digunakan dalam hal mencari solusi optimal dalam pengembalian uang pada vending machine dengan hanya memberikan uang koin Rp1.000 dan Rp500 dengan syarat jika pembeli membeli minuman yang harganya tidak bulat ribuan, maka sistem kembaliannya yaitu dengan memberikan uang kembalian 1 keping uang koin 500 dan sekian keping uang 1.000. Misal, pembeli ingin membeli minum mizone dengan harga 5.500 rupiah. Uang yang dimasukkan pembeli ke mesin sejumlah 10.000 rupiah. Berarti uang kembalian yang dikeluarkan mesin adalah 4.500 rupiah, maka pembeli akan memperoleh nominal uang kembalian yaitu 4 keping uang 1.000 dan 1 keping uang 500.

\section{HASIL DAN PEMBAHASAN}

Penelitian ini menghasilkan Sistem implementasi FSA dengan simulasi vending machine pada aplikasi android yang dirancang 
dengan menggunakan UML (Unified Modelling Language) yang terdiri dari user dan admin.

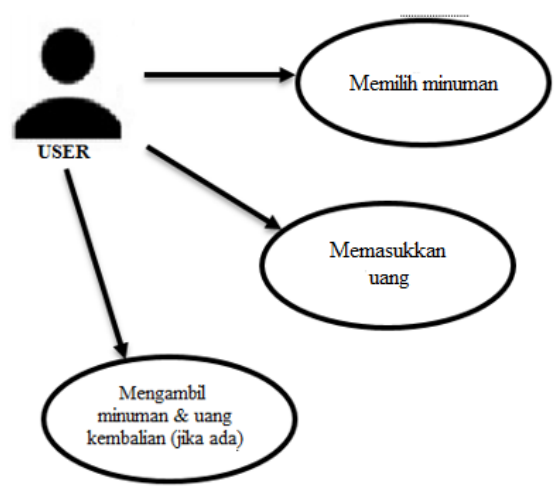

Gambar 3 Usecase Diagram User.

User dapat melakukan perintah memilih minuman, memasukan uang dan mengambil minuman dan uang kembaian (jika ada). Admin dapat melakukan perintah login, mengatur stok produk, dan mengambil uang.

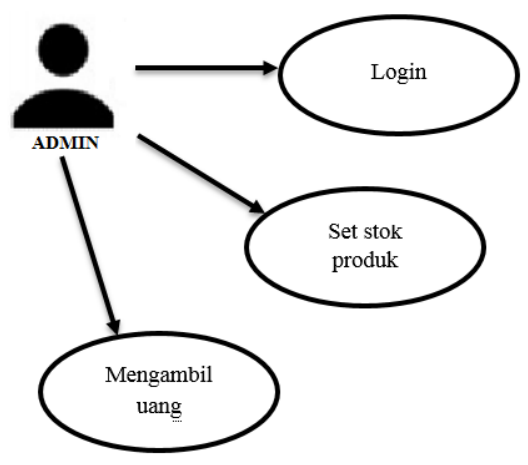

\section{Gambar 4 Usecase Diagram Admin}

Activity diagram menggambarkan sebuah alur dari rangkaian kegiatan yang ada pada sistem yang sedang dirancang. Jika vending machine dijalankan oleh user, maka activity diagram akan tergambar seperti gambar 5 .

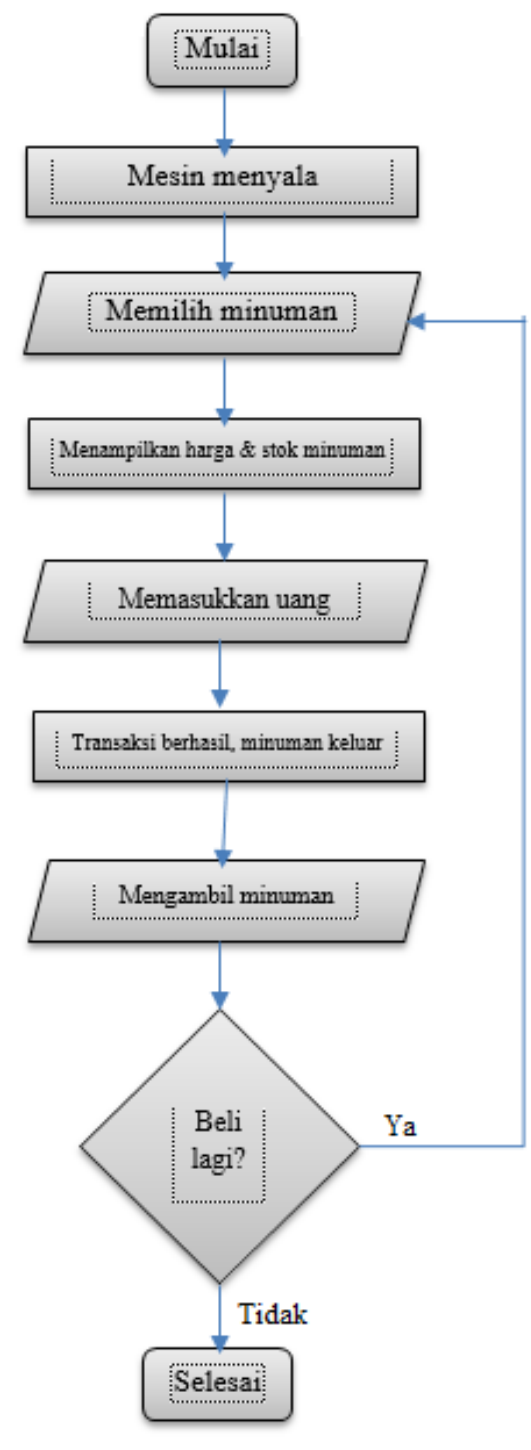

Gambar 5. Activity Diagram User

User mulai menjalankan mesin, kemudian memilih minuman yang diinginkan dan memasukkan uang sesuai yang tertera, kemudian sistem akan mengecek dan menyamakan antara input (uang) dan output (minuman) yang dipilih, jika sudah sesuai, maka vending machine akan mengeluarkan output (minuman) sesuai keinginan dan sistem akan mengurangi stok minuman, lalu tahap terakhir, user mengambil minuman yang telah dikeluarkan vending machine. Apabila user ingin membeli lagi, alurnya akan terulang mulai dari memilih minuman ke vending machine.

Kemudian activity diagram admin dapat dilihat pada gambar 6 . 


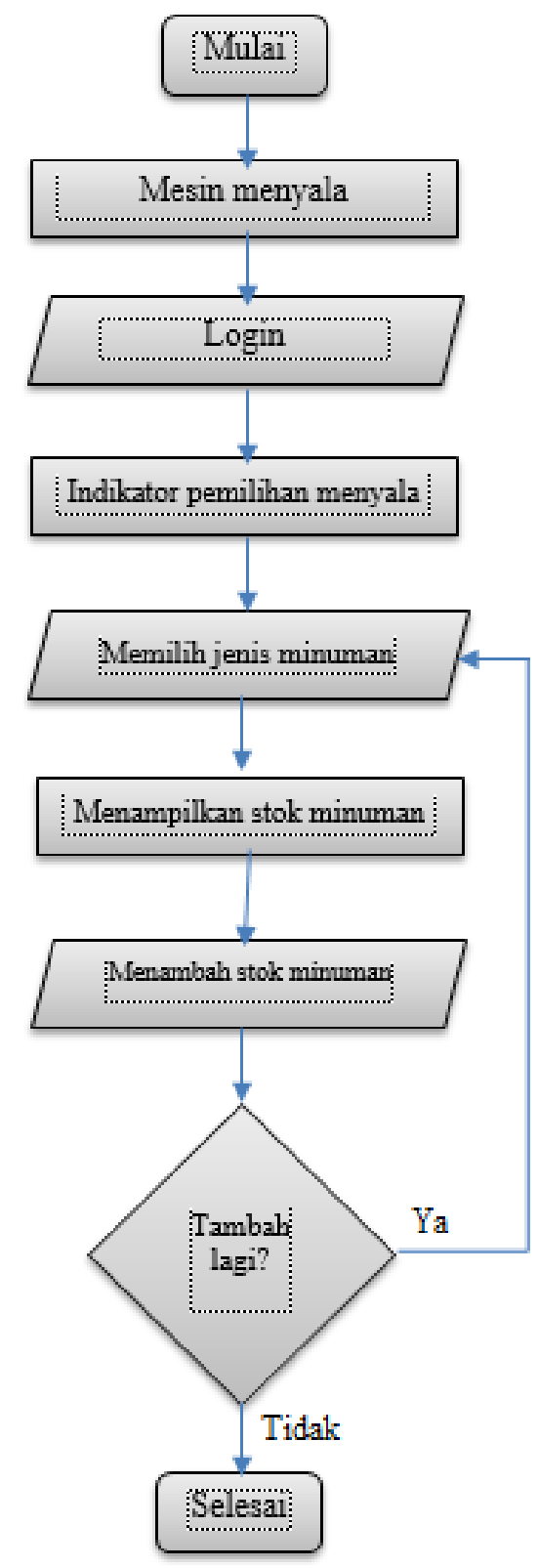

Gambar 6. Activity Diagram Admin

Activity diagram admin tergambar perihal mengisi ulang stok minuman. Dimulai dari login, kemudian sistem akan menampilkan informasi minuman yang akan tampil didalam vending machine, kemudian admin melihat stok minuman, jika dirasa telah menipis maka stok minuman akan ditambah, dan jika tidak, activity diagram selesai sampai tahap tersebut.

Penelitian ini menghasilkan sebuah rancangan user interface implementasi finite state automata (FSA) dengan simulasi vending machine pada aplikasi android menggunakan bahasa pemrograman.
Tampilan user pada saat pertama kali membuka aplikasi android dengan menu pilihan pada vending machine adalah minuman Mizone

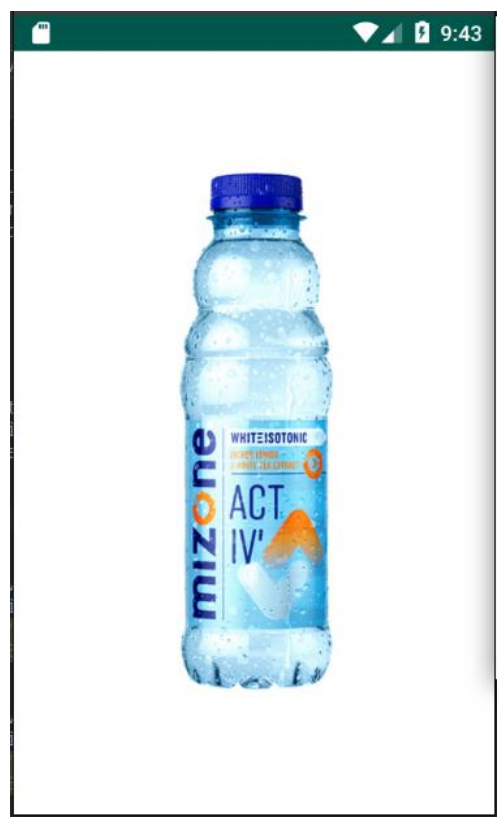

Gambar 7. Tampilan User Dengan minuman "mizone"

Tampilan user pada aplikasi android jika user melakukan swipe ke arah kanan, maka akan muncul tampilan pada vending machine dengan pilihan minuman berupa Pocari Sweat

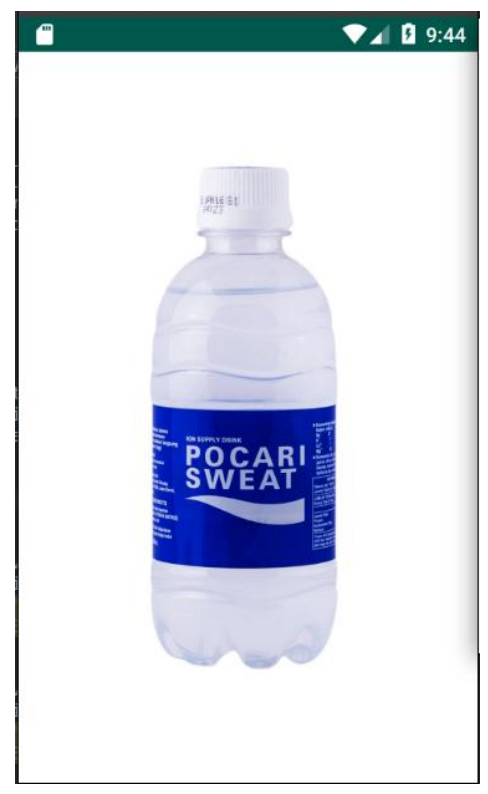

Gambar 8. Tampilan User Dengan Minuman Pocari Sweat 
Tampilan user pada aplikasi android jika user melakukan swipe ke arah kanan, maka akan muncul tampilan pada vending machine dengan pilihan minuman berupa Hydro Coco

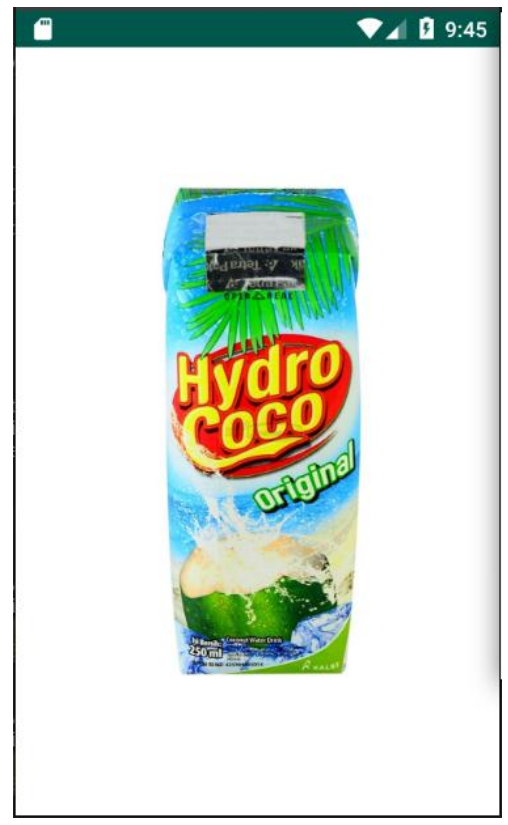

Gambar 9. Tampilan User Dengan Minuman Hydro Coco

User ketika telah memilih jenis minuman, maka akan keluar tampilan gambar produk yang dipilih beserta harga dan jumlah stok minuman.

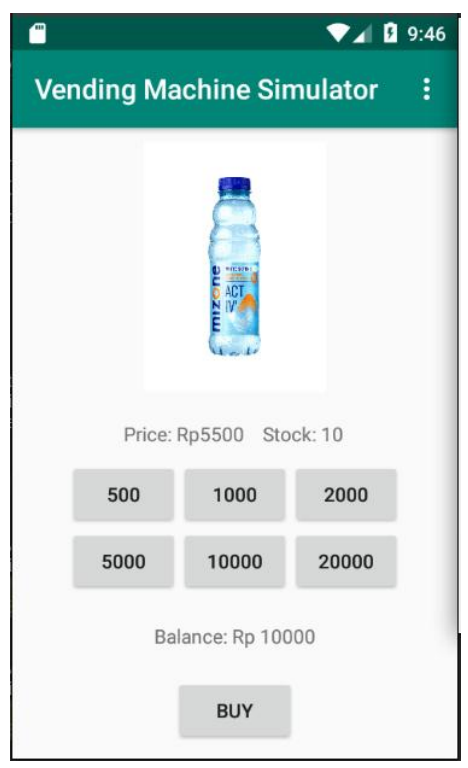

Gambar 10. Tampilan User Setelah Memilih Minuman Mizone
Ketika user telah membeli minuman yang dipilih, maka transaksi berhasil, dan akan ditampilkan rincian harga dan kembaliannya.

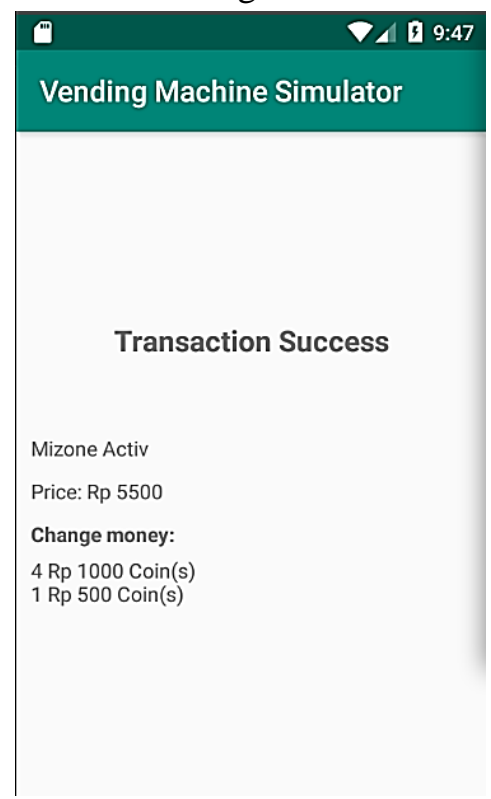

Gambar 11. Tampilan User Setelah Proses Pembelian Dilakukan

Tampilan ketika admin login dengan memasukkan password.

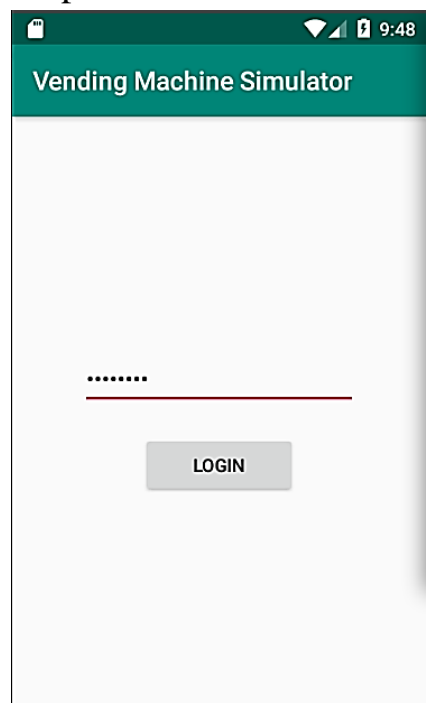

\section{Gambar 12. Tampilan Halaman Login Admin}

Setelah login, maka akan keluar tampilan pilihan "set item stock" untuk menambahkan jumlah produk dan "withdraw" untuk mengambil uang. 


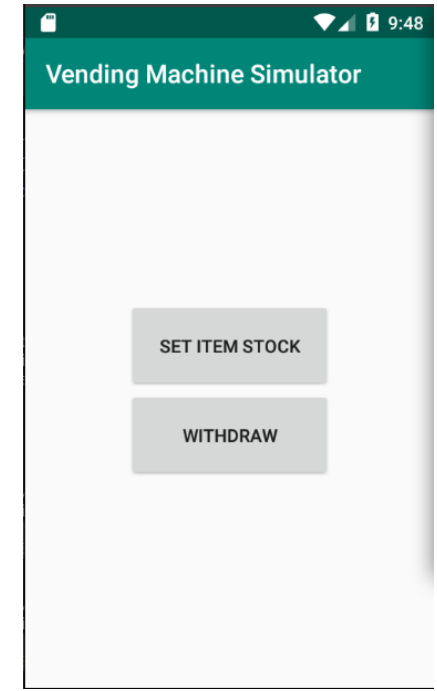

Gambar 13. Tampilan Admin Setelah Login

Ketika admin memilih "set item stock" maka admin akan memasukkan jumlah produk yang akan ditambahkan.

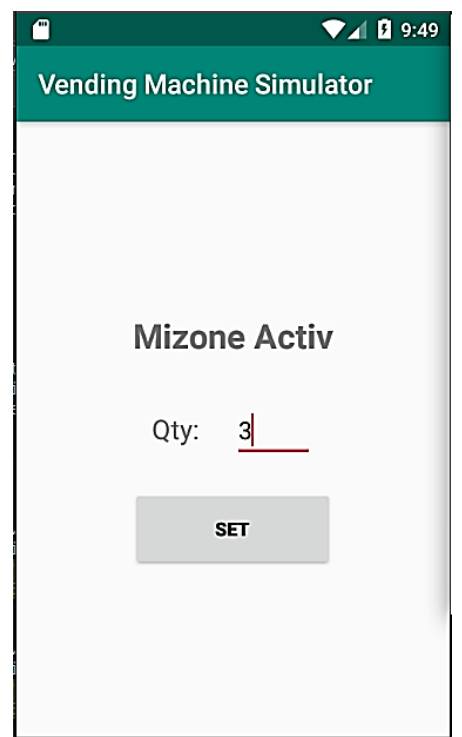

Gambar 14. Tampilan Admin Untuk Menambah Stok Produk

Ketika admin memilih "withdraw" maka akan ditampilkan sejumlah uang hasil yang kemudian diambil oleh admin.

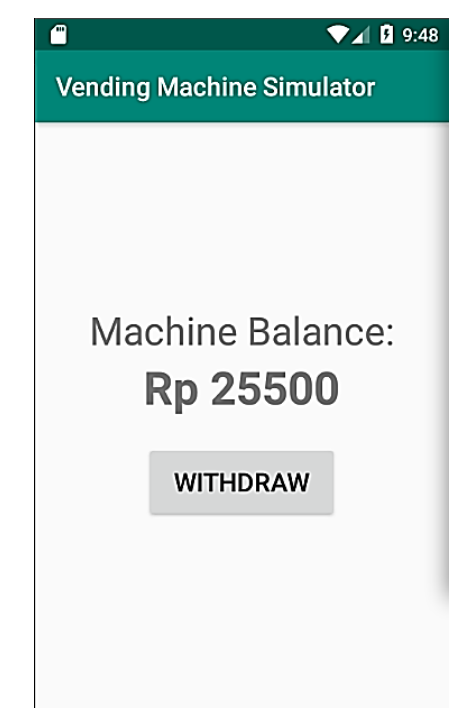

Gambar 15. Tampilan Admin Untuk Mengambil Uang

\section{SIMPULAN}

Dari hasil penelitian implementasi Finite State Automata (FSA) dengan simulasi vending machine pada android, hasil FSA menunjukan penggunaan vending machine sangat sederhana. Penggunaan FSA sebagai dasar pengoperasian vending machine menjelaskan konsep kerja vending machine secara detail sehingga mudah untuk dipahami. Dari hasil diagram FSA dapat di buat konsep logika sederhana untuk implementasi vending machine.

\section{DAFTAR RUJUKAN}

F. Utdirartatmo. 2005. Teori Bahasa dan Otomata, Kedua. Yogyakarta: Graha Ilmu.

K. Kim, D. Park, H. Bang, G. Hong, and S. Jin. 2014. Smart Coffee Vending Machine Using Sensor and Actuator Networks, pp. 71-72.

L. Glenn. 2013. Rancang Bangun Aplikasi Pembelajaran Budaya Indonesia Untuk Anak Sekolah Dasar Berbasis Android. Jurnal Ilmiah Komputasi, vol 12 (1). STMIK Jakarta, hal 1-6. 
M. S. A. S, M. Syai, J. Endrasmono, S. T. Sarena, L. Subiyanto, and A. S. Setyoko. 2017. Smart Vending Machine Based on SMS Gateway For General Transactions, no. 2, pp. 34-39.

N. Safat. 2012. Pemrograman Aplikasi Mobile Smartphone dan Tablet PC Berbasis Android. Bandung: Informatika Bandung.

Rudi. 11 Juni 2014. 6 Inovasi tebaru Vending Machine. dalam http://www.ceriwis.web.id/lounge/94686 4- wow-inilah-6-inovasi-terbaru-mesinpenjual.html, diakses pada 8 November 2019.
Sudiadi dan Teguh Rizadi. 2017. Komputer Global Informatika. Sekolah Tinggi Manajemen Informatika dan MDP.

Wamiliana, Ossy Dwi Endah W, Marisa Ayu Rahmadhani. 2013. Pengembangan Algoritma Mow dan Generalisasi Bahasa Automata untuk Proses Pembuatan Minuman Serta Pengembalian Uang pada Desain Mesin Kopi Otomatis. Jurnal Ilmu Komputer, Vol.1, No. 2.

Widyasari. 2011. Telaah Teoritis Finite State Automata dengan Pengujian Hasil pada Mesin Otomata. Pontianak : Sekolah Tinggi Manajemen Informatika dan Komputer. 